\title{
THE IMPORTANCE OF DEVELOPING STUDENTS' TECHNOLOGICAL SKILLS IN HIGHER EDUCATION FOR THEIR FUTURE QUALITY OF LIFE
}

\author{
A. L. Rodrigues ${ }^{1}$, L. Cerdeira ${ }^{2}$, M. L. Machado-Taylor ${ }^{3}$, H. Alves ${ }^{4}$, \\ 1;2Instituto de Educação, Universidade de Lisboa (Portugal) \\ ${ }^{3}$ Centro de Investigação em Políticas do Ensino Superior (CIPES) (Portugal) \\ ${ }^{4}$ Universidade da Beira Interior (Portugal)
}

\begin{abstract}
Digital technologies have been playing an increasingly relevant role in the personal, social, academic, and professional lives of all citizens, especially after the Covid-19 pandemic. As a result, the technological skills development is a central issue for any country's education and development policies. Throughout school life, young people in primary and secondary education, and later, in Higher Education Institutions (HEls), to a greater or lesser degree, have the opportunity to build and develop various skills, namely technological. These will certainly be useful in their academic, social, and professional future life. In this way, it is intended to study which technological skills are built and developed by higher education students and what their perception about the importance of technological skills in employment, personal life, and social relationships in the future. There will be a literature review that will serve as a basis for the design of an online questionnaire to be applied to HEls students, to verify which areas of technological skills (based on the European Digital Competence Framework for Citizens) are most developed and understand repercussions they may have on the professional, personal, and social future of these students and for their future quality of life. The questionnaire was tested, reviewed by experts, and applied to students from three public education institutions located in the North, Centre, and South of Portugal. A summary of the results obtained with this questionnaire is presented.
\end{abstract}

Keywords: Technological skills, higher education, quality of life.

\section{INTRODUCTION}

This paper is included in the U-Value research project, The impact of Higher Education Institutions on the quality of life of their regions, which aims to study the impact that HEls may have on the quality of life and sustainability of their regions, and the characterization of their efficiency in the transformation of funds in outputs that influence the quality of life of the populations and the sustainability of their regions of influence.

In this context, it is intended to carry out a theoretical reflection on the role that technology, in particular, can play in the relationship that HEls establish with the community, namely: i) in the technological skills development of the population and ii) in the ways of using digital technologies in employment, personal/family life and social relationships.

The technological skills are already essential in today's knowledge society and appear to be crucial in the future on the life satisfaction of the public, alongside generic skills. In a study developed through multiple regression analysis using demographic variables as controlled constructs, it was found that the main skills of the 21 st century, critical thinking, problem solving, communication and technological skills, as well as age and income, have a positive impact on life satisfaction [1].

Information Communication Technologies (ICTs) especially the Internet and the web has changed every aspect of human life, from individual social life to the industry modernization and the economic growth of nations. Technology has critical to our wellbeing and above all it has become a necessity that contributes to expanding the possibilities of having a better quality of life (QoL), fundamental element for the sustainable development of countries and regions.

In a study on the ICT use, and European citizens' assessment of their QoL, results reveal a clear relationship between technology and quality of life. Regarding the QoL factor, the dimensions Life Satisfaction (Trust and Safety), Mobility (Culture and Sports), Integration (Sustainability) and Public Services were examined. It was concluded that life satisfaction increases with greater use of 
technologies and ICT preparedness. Mobility rated more highly by citizens if there is a clear Research \& Development (R\&D) investment strategy. Therefore, the digital citizen is happier living in regions with technological capacity, which invest in R\&D, and which are committed to achieving sustainable growth [2].

Another study on the role of ICTs on the QoL relying on secondary data from 121 countries was developed in 2018 based on structuring theory. The results show that digital inclusion and ICT access significantly influence QoL at the global level and provided key insights that explain how QoL may be enhanced through ICTs. However, results reveal that the use of ICT is significant in the linkage between digital inclusion and QoL but not for the linkage between ICT access and QoL [3].

The findings from this study also showed some policy implications. They show that ICT access and digital inclusion significantly influence the QoL. Therefore, developing QoL policies, policymakers should provide ICT access creating a digitally enabled society. In this regard, the access to affordable ICTs (through lower mobile tariffs and lower handset prices) will enable people to enhance their skills, avoiding social exclusion and promote their QoL.

After the COVID-19 pandemic the need to develop technological competence was evident and the privileged location for this feat will be throughout school life, from primary and secondary education to Higher Education. Thus, the pandemic has had a severe impact on Education including in higher education. Especially at this level, it was a quick change from face-to-face lectures to online learning. However, the crisis raises questions about the value offered by a university education which includes educational content, but also networking and social opportunities. In this way, universities will need to reinvent their learning environments and should promote the development of technological skills in students and teachers [4].

Therefore, this study aims to analyze which technological skills are built and developed by higher education students and what their perception about the importance of technological skills in employment, personal life, and social relationships in the future.

\section{METHODOLOGY}

This paper was based on a literature review and the construction and application of a questionnaire to HEls students.

The construction of the questionnaire was based on the areas of competence of the European Digital Competence Framework for Citizens [5]. This aims to analyse: i) how digital technologies (TD) are used by higher education students in Portugal, at a personal / social and academic / professional level; ii) what technological skills students develop throughout their academic career; and iii) what is the impact / relevance of TD on their professional future and quality of life.

The questionnaire was tested with four students, one from each level of education, and reviewed by tree experts. Posteriorly, it was applied to students from two faculties of the universities of Beira Interior and Lisbon, and a polytechnic institute, of public education, located in the North, Centre and South of Portugal, between November 2020 and January 2021 [6].

In terms of structure, the questionnaire was divided into four parts: Personal data; Use of TD; Development of technological skills; and Impact of TD. It included 13 closed-answer questions and 3 open-answer questions. 217 valid responses were received.

The preliminary analysis of the data was carried out based on descriptive statistics, and the open questions were analysed using the content analysis technique [7].

\section{RESULTS}

The preliminary results obtained based on the literature review and questionnaire analysis allow a better understanding of the importance of the development of technological skills and leave some clues about the students' perception regarding their influence on their professional future and quality of life.

Of the 217 students who answered the questionnaire, $71 \%$ are female, and $29 \%$ are male. The majority, $44 \%$, are under 24 years old, however $29 \%$ of respondents are 40 years old or more. Regarding level of education attended, $42 \%$ are in Graduation, $36 \%$ in Master/ Graduate and $18 \%$ in Doctorate (view Figure 1). 


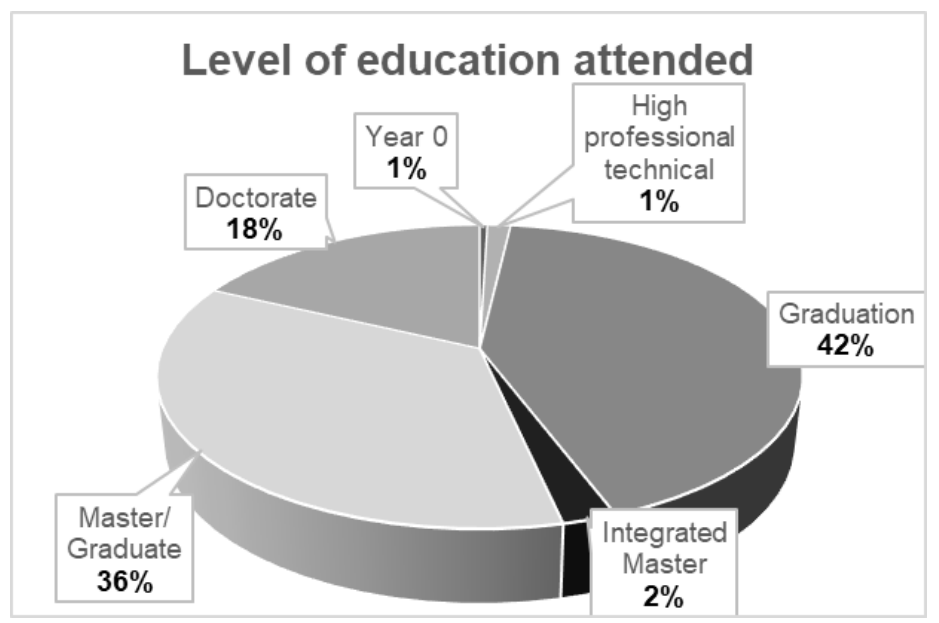

Figure 1. Level of education attended.

Considering the main digital equipment used, respondents mainly use, every day, the Smartphone $(82 \%+6 \%)$ and the Portable computer $(59 \%+20 \%)$. The Desktop computer, Tablet and simple Mobile phone are never or less than once a week used by $70 \%, 68 \%$ and $78 \%$, respectively (Table 1.).

Table 1. Frequency of digital equipment use.

\begin{tabular}{|c|c|c|c|c|c|c|c|c|c|c|}
\hline & \multicolumn{2}{|c|}{$\begin{array}{l}\text { Desktop } \\
\text { computer }\end{array}$} & \multicolumn{2}{|c|}{$\begin{array}{l}\text { Portable } \\
\text { computer }\end{array}$} & \multicolumn{2}{|c|}{ Tablet } & \multicolumn{2}{|c|}{ Smartphone } & \multicolumn{2}{|c|}{ Mobile phone } \\
\hline $\begin{array}{l}\text { Never or less than } \\
\text { once a week }\end{array}$ & 151 & $70 \%$ & 6 & $3 \%$ & 147 & $68 \%$ & 9 & $4 \%$ & 170 & $78 \%$ \\
\hline A few times a week & 10 & $5 \%$ & 37 & $17 \%$ & 32 & $15 \%$ & 18 & $8 \%$ & 11 & $5 \%$ \\
\hline Once a week & 6 & $3 \%$ & 2 & $1 \%$ & 12 & $6 \%$ & 0 & $0 \%$ & 5 & $2 \%$ \\
\hline $\begin{array}{l}\text { Every day, } 1 \text { or } 2 \\
\text { times }\end{array}$ & 13 & $6 \%$ & 43 & $20 \%$ & 9 & $4 \%$ & 12 & $6 \%$ & 4 & $2 \%$ \\
\hline $\begin{array}{l}\text { Every day, several } \\
\text { times }\end{array}$ & 37 & $17 \%$ & 129 & $59 \%$ & 17 & $8 \%$ & 178 & $82 \%$ & 27 & $12 \%$ \\
\hline
\end{tabular}

The most usually used applications and software signalized were Text editor (e.g., Word) with 94\%, WhatsApp with 93\%, Learning platform (e.g., Moodle, Classroom, Teams) with 87\%, Presentations (e.g., PowerPoint) with $84 \%$ and Instagram with $73 \%$ (Table 2.).

Table 2. Applications/ software usually used.

\begin{tabular}{l|r|r}
\hline \hline Text editor (e.g., Word) & 204 & $94 \%$ \\
\hline Spreadsheet (e.g., Excel) & 128 & $59 \%$ \\
\hline Presentations (e.g., PowerPoint) & 182 & $84 \%$ \\
\hline Learning platform (e.g., Moodle, Classroom, & 189 & $87 \%$ \\
\hline Teams) & 110 & $51 \%$ \\
\hline Questionnaires (e.g., Google Forms, Kahoot) & 52 & $24 \%$ \\
\hline Data processing programs (e.g., SPSS, Nvivo) & & \\
\hline Bibliographic References (e.g., EndNote, & 58 & $27 \%$ \\
\hline Mendeley) & 155 & $71 \%$ \\
\hline Facebook & 202 & $93 \%$ \\
\hline WhatsApp & 159 & $73 \%$ \\
\hline Instagram & 65 & $30 \%$ \\
\hline Linkedln & 11 & $5 \%$ \\
\hline Twitter & \multicolumn{2}{|l}{} \\
\hline \hline
\end{tabular}


In terms of frequency by type of digital technologies use, every day, most respondents use them in their lives Personal /Social $(74 \%+15 \%)$, Academic /Professional $(54 \%+27 \%)$ and Teaching /Learning $(47 \%+27 \%)$. The Telecommuting is never or less than once a week used for $43 \%$ of respondents, $17 \%$ use it a few times a week, and $21 \%+10 \%$ use it every day (Table 3. .).

Table 3. Frequency by type of use of digital technologies.

\begin{tabular}{|c|c|c|c|c|c|c|c|c|}
\hline \multirow[b]{2}{*}{$\begin{array}{l}\text { Never or less than once } \\
\text { a week }\end{array}$} & \multicolumn{2}{|c|}{$\begin{array}{c}\text { Personal/ } \\
\text { Social }\end{array}$} & \multicolumn{2}{|c|}{$\begin{array}{c}\text { Academic/ } \\
\text { Professional }\end{array}$} & \multicolumn{2}{|c|}{$\begin{array}{l}\text { Teaching/ } \\
\text { Learning }\end{array}$} & \multicolumn{2}{|c|}{ Telecommuting } \\
\hline & 7 & $3 \%$ & 7 & $3 \%$ & 3 & $1 \%$ & 94 & $43 \%$ \\
\hline A few times a week & 8 & $4 \%$ & 25 & $12 \%$ & 39 & $18 \%$ & 37 & $17 \%$ \\
\hline Once a week & 9 & $4 \%$ & 10 & $5 \%$ & 15 & $7 \%$ & 18 & $8 \%$ \\
\hline Every day, 1 or 2 times & 33 & $15 \%$ & 58 & $27 \%$ & 58 & $27 \%$ & 22 & $10 \%$ \\
\hline $\begin{array}{l}\text { Every day, several } \\
\text { times }\end{array}$ & 160 & $74 \%$ & 117 & $54 \%$ & 102 & $47 \%$ & 46 & $21 \%$ \\
\hline
\end{tabular}

Among the most marked activities with digital technologies developed are: Search engine navigation and searches (e.g., Google) with $97 \%$, Send messages and/ or use email with $96 \%$, Perform academic work with $89 \%$, Use social networks (Facebook, Tweeter, Instagram, etc.) with $88 \%$, Use learning support platforms (e.g., Moodle, Classroom, Teams) and Chat and/ or videoconference both with $87 \%$ (Table 4.).

Table 4. Activities developed with digital technologies.

\begin{tabular}{l|r|r}
\hline \hline Search engine navigation and searches (e.g., Google) & 210 & $97 \%$ \\
\hline Watching movies/ videos and/ or listening to music & 178 & $82 \%$ \\
\hline Chat and/ or videoconference & 189 & $87 \%$ \\
\hline Send messages and/ or use email & 208 & $96 \%$ \\
\hline Online shopping & 129 & $59 \%$ \\
\hline Use social networks (Facebook, Tweeter, Instagram, etc.) & 191 & $88 \%$ \\
\hline Use academic/ professional social networks (Linkedln, & 98 & $45 \%$ \\
\hline ResearchGate, etc.) & 180 & $83 \%$ \\
\hline Attend classes and/ or videoconferences & 194 & $89 \%$ \\
\hline Perform academic work & 188 & $87 \%$ \\
\hline Use learning support platforms (e.g., Moodle, Classroom, Teams) & 152 & $70 \%$ \\
\hline Consult databases and bibliography & 102 & $47 \%$ \\
\hline Perform professional tasks & &
\end{tabular}

Taking into account the Competence Areas from European Digital Competence Framework for Citizens [5], respondents were asked about the degree of technological skills developed during higher education. With the highest percentage of Good responses, the following Technological skills were recorded "Adapt my searching strategy to find the most appropriate information and content in digital environments", "Manipulate information for easier organization, storage and retrieval" and "Use and select appropriate digital technologies to interact". With Very good stand out also "Adapt my searching strategy to find the most appropriate information and content in digital environments" and "Share information and content using a variety of digital tools". The Technological skills referred to as Weak developed were "Apply rules of copyright and licenses", "Choosing solutions to protect the environment from the impact of digital technologies" and "Solve problem situations in digital environments". 
When asked about the degree of importance, at a professional level in their future, of the skills listed, the respondents referred in a higher percentage with Very important "Search and select online credible information and content" and "Use online security and privacy rules". With Little importance were more marked "Make presentations online" and "Try new digital tools".

\section{CONCLUSIONS}

It was possible to conclude that it is important to analyze which technological skills built and developed by students in higher education, in the different areas of competence, to promote their balanced development in the future in each of them areas.

We found that most respondents use smartphone and portable computer, and the most used applications/ software were the text editor, learning platforms, presentations, WhatsApp, and Instagram, especially in your Personal/ Social, Academic/ Professional and Teaching/ Learning life. The activities with digital technologies most developed are "Search engine navigation and searches", "Send messages and /or use email", "Perform academic work" and "Use social networks".

Regarding the skills they consider having developed more in higher education, they stressed "Adapt my searching strategy to find the most appropriate information and content in digital environments", "Share information and content using a variety of digital tools", "Manipulate information for easier organization, storage and retrieval" and "Use and select appropriate digital technologies to interact". About their perception of the importance of technological skills in employment, personal life, and social relationships in the future, they confirmed the importance of all mentionedand the most referred to as important were "Search and select online credible information and content" and "Use online security and privacy rules".

However, more studies are needed for a deeper understanding of which and how the areas of technological competences need to be further promoted, namely as relevant information for HEl's and public policy makers.

\section{ACKNOWLEDGEMENTS}

This article is part of the U-Value research project (PTDC/EGE-OGE/29926/2017) funded by Fundação para a Ciência e a Tecnologia (FCT).

Project team include Helena Alves, Maria de Lourdes Taylor, Luísa Cerdeira, Ana Luísa Rodrigues, Belmiro Cabrita, Eugénia Pedro, João Leitão, Mário Raposo, Marta Alves, Tomás Patrocínio e Pedro Mucharreira.

\section{REFERENCES}

[1] O. Leelakulthanit, "The impact of 21st century skills on the life satisfaction of the general public", in Journal of Applied Economic Sciences, Volume XIII, Winter, vol. 7, no. 61, pp. 2064 - 2075, 2018. Retrieved from http://search.ebscohost.com/login.aspx?direct=true\&profile=ehost\&scope=site\&authtype=crawle r\&jrnl=18436110\&AN=135410196\&h=8T101E4Jsqdjj2ro\%2B7YYKJ6DLdZp4cEKNrllySntxLt\% 2FI2xWiPncBRA2Av9fUdgGtYjWdWw0vgcEAkPSnW7dmg\%3D\%3D\&crl=c.

[2] D. Nevado-Peña, V-R. López-Ruiz, and J-L. Alfaro-Navarro, "Improving Quality of Life Perception with ICT Use and Technological Capacity in Europe", Technological Forecasting \& Social Change, vol.148, no.119734, 2019. doi:10.1016/j.techfore.2019.119734.

[3] M. D. Alhassan, and I. O. Adam, "The effects of digital inclusion and ICT access on the quality of life: A global perspective", Technology in Society, Volume 64, no.101511, 2021. doi.org/10.1016/j.techsoc.2020.101511.

[4] OECD (Organisation for Economic Cooperation and Development). The Impact of COVID-19 on Education - Insights from Education at a Glance 2020: OECD Indicators, Paris: OECD Publishing. doi.org/10.1787/69096873-en.

[5] S. Carretero, R. Vuorikari, and Y. Punie, DigComp 2.1: The Digital Competence Framework for Citizens with eight proficiency levels and examples of use, Luxembourg: Publications Office of the European Union, 2017. doi.org/10.2760/38842. 
[6] L. L. Cohen, L. Manion, and K. Morrison, Research Methods in Education, Oxford, UK: Routledge Publishers, 2007.

[7] L. Bardin, Análise de conteúdo [Content analysis]. Lisboa: Edições 70, Lda, 2011. 